\title{
A mechanistic model of an upper bound on oceanic carbon export as a function of mixed layer depth and temperature
}

\author{
Zuchuan Li and Nicolas Cassar \\ Division of Earth and Ocean Sciences, Nicholas School of the Environment, Duke University, Durham, North Carolina, USA \\ Correspondence to: Zuchuan Li (zuchuan.li@duke.edu)
}

Received: 21 June 2017 - Discussion started: 26 June 2017

Revised: 19 September 2017 - Accepted: 28 September 2017 - Published: 14 November 2017

\begin{abstract}
Export production reflects the amount of organic matter transferred from the ocean surface to depth through biological processes. This export is in large part controlled by nutrient and light availability, which are conditioned by mixed layer depth (MLD). In this study, building on Sverdrup's critical depth hypothesis, we derive a mechanistic model of an upper bound on carbon export based on the metabolic balance between photosynthesis and respiration as a function of MLD and temperature. We find that the upper bound is a positively skewed bell-shaped function of MLD. Specifically, the upper bound increases with deepening mixed layers down to a critical depth, beyond which a long tail of decreasing carbon export is associated with increasing heterotrophic activity and decreasing light availability. We also show that in cold regions the upper bound on carbon export decreases with increasing temperature when mixed layers are deep, but increases with temperature when mixed layers are shallow. A meta-analysis shows that our model envelopes field estimates of carbon export from the mixed layer. When compared to satellite export production estimates, our model indicates that export production in some regions of the Southern Ocean, particularly the subantarctic zone, is likely limited by light for a significant portion of the growing season.
\end{abstract}

\section{Introduction}

Photosynthesis in excess of respiration at the ocean surface leads to the production of organic matter, part of which is transported to the deep ocean through sinking and mixing (Volk and Hoffert, 1985). This biological process, known as export production (also called the soft-tissue biological car- bon pump) lowers carbon dioxide $\left(\mathrm{CO}_{2}\right)$ concentrations at the ocean surface and facilitates the flux of $\mathrm{CO}_{2}$ from the atmosphere into the ocean (Falkowski et al., 1998; Ito and Follows, 2005; Sigman and Boyle, 2000).

Export production is frequently assumed to be a function of net community production (NCP), which is defined as the balance between net primary production (NPP) and heterotrophic respiration (HR) or the difference between gross primary production (GPP) and community respiration (CR; HR plus autotrophic respiration, AR; the abbreviations used in this study are presented in Table A; Li and Cassar, 2016):

$$
\mathrm{CO}_{2}+\mathrm{H}_{2} \mathrm{O} \underset{\underbrace{}_{\mathrm{NPP}} \underset{\mathrm{NCP}}{\stackrel{\mathrm{GPP}}{\mathrm{HR}}} \overleftarrow{\mathrm{AR}}}{\longrightarrow} \text { Organic matter }+\mathrm{O}_{2}
$$

Export production $=\mathrm{NCP}-\mathrm{MLD} \cdot \frac{\mathrm{d}(\mathrm{POC}+\mathrm{DOC})}{\mathrm{d} t}$,

where POC, DOC, and MLD represent particulate organic carbon, dissolved organic carbon, and mixed layer depth, respectively. If the organic carbon inventory (POC $+\mathrm{DOC})$ in the mixed layer is at steady state, NCP is equal to export production (Eq. 2). Without allochthonous sources of organic matter, if the organic matter inventory in the mixed layer decreases, NCP will be predicted to be transiently smaller than export production. Conversely, export may lag NPP (Henson et al., 2015; Stange et al., 2017), in which case NCP is expected to be greater than export production.

Net community production is in large part regulated by the availability of nutrients and light. Light availability exponentially decays with depth due to absorption by water and its constituents. The mixing of phytoplankton to depth therefore impacts phytoplankton physiology and productivity (Cullen and Lewis, 1988; Lewis et al., 1984), with the 
depth-integrated NPP expected to increase down to the euphotic depth. Respiration, however, is often modeled to be some function of organic matter concentration, which is expected to be constant with depth if homogeneously mixed within the mixed layer. Temperature is also believed to be an important control on carbon export because respiration is more temperature sensitive than photosynthesis (Laws et al., 2000; López-Urrutia et al., 2006; Rivkin and Legendre, 2001). Field observations confirm that NCP is generally lower at high temperatures and consistently low when mixed layers are deep. These patterns have been attributed to the balance between depth-integrated photosynthesis (controlled by the availability of nutrients and light) and respiration as a function of MLD and temperature (Cassar et al., 2011; Eveleth et al., 2017; Huang et al., 2012; Shadwick et al., 2015; Tortell et al., 2015). However, descriptions of the underlying mechanisms remain qualitative. Likewise, the effects of light and nutrients on carbon fluxes are difficult to disentangle. For example, high-nutrient, low-chlorophyll regimes in the Southern Ocean have been attributed to iron limitation (Boyd et al., 2000), deep mixed layers, and light limitation (Nelson and Smith, 1991; Mitchell and HolmHanse, 1991; Mitchell et al., 1991), or both (Sunda and Huntsman, 1997). To decompose the influence of light and nutrient availability on NCP, we define the upper bound on carbon export from the mixed layer $\left(\mathrm{NCP}^{*}\right)$ as the maximum export achievable should all limiting factors other than light (taking into account self-shading) be alleviated.

In his seminal paper, Sverdrup presented an elegant model to demonstrate that vernal phytoplankton blooms (i.e., organic matter accumulation at the ocean surface) may be driven by increased light availability when the MLD shoals above a critical depth ( $Z_{\mathrm{c}}$; Sverdrup, 1953). In our study, we build upon Sverdrup (1953) and derive a mechanistic model of an upper bound on carbon export based on the metabolic balance of photosynthesis and respiration in the oceanic mixed layer, in which the metabolic balance is derived from MLD, temperature, photosynthetically active radiation (PAR), phytoplankton maximum growth rate $\left(\mu_{\max }\right)$, and heterotrophic activity. Our approach is analogous to other efforts in which mechanistic models were derived to predict proxies for carbon export (e.g., Dunne et al., 2005 and Cael and Follows, 2016). We compare our NCP* model to observations and use this model in conjunction with satellite export production estimates to identify regions in the world's oceans where light may limit export production. Our key findings are that (1) using parameters available in the literature, the modeled upper bound envelopes field observations of $\mathrm{O}_{2}$ / Ar-derived NCP and export production derived from ${ }^{234} \mathrm{Th}$ and sediment traps, and (2) the model identifies regions of the Southern Ocean where carbon export is likely limited by light during part of the growing season. (a)

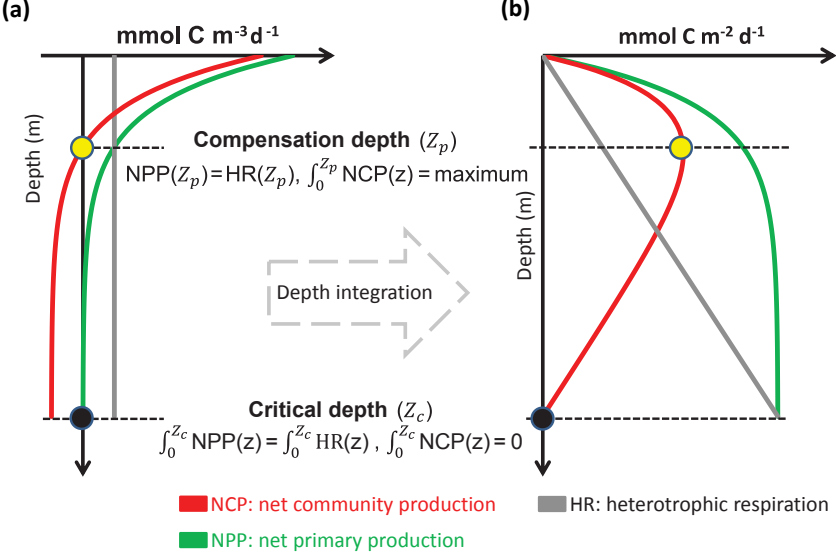

Figure 1. Schematic diagram of depth profiles of net community production (NCP), net primary production (NPP), and heterotrophic respiration (HR). Yellow and black dots represent the compensation and critical depths, respectively.

\section{Model description and comparison to observations}

\subsection{Net community production and light availability}

A conceptual representation of the metabolic balance between volumetric NCP, NPP, and HR profiles is presented in Fig. 1a. According to Eq. (1), the volumetric NCP flux at a given depth $(z)$ in the mixed layer results from the difference between volumetric NPP and HR:

$\operatorname{NCP}(z)=\operatorname{NPP}(z)-\operatorname{HR}(z)$,

where $z$ increases with depth. $\operatorname{NPP}(z)$ is a function of the autotroph intrinsic growth rate $(\mu)$ times the biomass concentration $(C)$. Assuming that the effect of nutrients and light on photosynthetic rates abides by Michaelis-Menten kinetics and neglecting the effect of photoinhibition (Dutkiewicz et al., 2001; Huisman and Weissing, 1994), NPP(z) may be expressed as follows:

$\operatorname{NPP}(z)=\mu(z) \cdot C=\frac{N}{N+k_{m}^{N}} \cdot \frac{I(z)}{I(z)+k_{m}^{\mathrm{I}}} \cdot \mu_{\max } \cdot C$,

where $\mu_{\max }$ is the maximum intrinsic growth rate of the autotrophic community, $N$ and $k_{m}^{\mathrm{N}}$ represent the nutrient concentration and half-saturation constant, respectively, and $I$ and $k_{m}^{\mathrm{I}}$ represent the irradiance level and half-saturation constant, respectively; $\mu_{\max }, N, k_{m}^{\mathrm{N}}, k_{m}^{\mathrm{I}}$, and $C$ are assumed to be constant or uniform within the mixed layer. The first two terms on the right-hand side of Eq. (4) account for the effect of nutrient and light availability on autotrophic growth rates, and they are hereafter defined as follows for simplicity:

$$
\begin{aligned}
& N_{m}=\frac{N}{N+k_{m}^{\mathrm{N}}}, \\
& I_{m}(z)=\frac{I(z)}{I(z)+k_{m}^{\mathrm{I}}} .
\end{aligned}
$$


$I(z)$ is modeled as an exponential decay of PAR just beneath the water surface $\left(I_{0}\right)$ :

$I(z)=I_{0} \cdot e^{-K_{\mathrm{I}} \cdot z}$,

where $K_{\mathrm{I}}$ is the light attenuation coefficient, which is assumed to be independent of depth in the mixed layer.

As a first approximation, we assume that $\operatorname{HR}(z)$ is proportional to $C$ as in previous studies (Dutkiewicz et al., 2001; Huisman and Weissing, 1994; Rivkin and Legendre, 2001; Sverdrup, 1953; White et al., 1991):

$\mathrm{HR}(z)=r_{\mathrm{HR}} \cdot C$,

where $r_{\mathrm{HR}}$ represents the intrinsic heterotrophic respiration rate, which is assumed to be dependent on temperature (see below) and independent of depth. In reality, $\operatorname{HR}(z)$ is likely best modeled as a function of the concentration of labile organic matter - an additional term could be included to account for the relationship of total labile organic matter to $C$.

$\mathrm{NCP}$ integrated over the mixed layer (NCP $(0, \mathrm{MLD}))$ can be derived from Eqs. (3)-(7):

$$
\begin{gathered}
\operatorname{NCP}(0, \operatorname{MLD})=\operatorname{NPP}(0, \operatorname{MLD})-\operatorname{HR}(0, \operatorname{MLD}) \\
=\int_{0}^{\operatorname{MLD}} \operatorname{NPP}(z) \mathrm{d} z-\int_{0}^{\operatorname{MLD}} \operatorname{HR}(z) \mathrm{d} z=N_{m} \\
\cdot I_{m}(0, \operatorname{MLD}) \cdot \mu_{\max } \cdot C-r_{\mathrm{HR}} \cdot \operatorname{MLD} \cdot C .
\end{gathered}
$$

The first term on the right side of Eq. (8) represents NPP integrated over the mixed layer (NPP( $0, M L D)$ ), which is equivalent to the product of $\int_{0}^{\mathrm{MLD}} \mu(z) \mathrm{d} z$ and $C$, where the former term is modeled to be a function of $\mu_{\max }$ conditioned by nutrient and light availability within the mixed layer. $I_{m}(0, \mathrm{MLD})$ can be derived as follows:

$$
\begin{aligned}
& I_{m}(0, \mathrm{MLD})=\int_{0}^{\mathrm{MLD}} I_{m}(z) \mathrm{d} z \\
& \quad=-\frac{1}{K_{\mathrm{I}}} \cdot \ln \left(\frac{I_{0} \cdot e^{-K_{\mathrm{I}} \cdot \mathrm{MLD}}+k_{m}^{\mathrm{I}}}{I_{0}+k_{m}^{\mathrm{I}}}\right) .
\end{aligned}
$$

NCP integrated over the mixed layer (Eq. 8) is a bell-shaped function of MLD as depicted in the schematic diagram in Fig. $1 b$.

\subsection{Net community production and phytoplankton biomass concentration}

As can be seen from Eq. (8), NCP(0, MLD) is a direct function of $C$ because NPP( 0, MLD) and HR( 0, MLD) are proportional to $C$. $\mathrm{NCP}(0, \mathrm{MLD})$ is also an indirect function of $C$ due its effect on light attenuation (i.e., $K_{\mathrm{I}}$ ). The attenuation coefficient $K_{\mathrm{I}}$ can be divided into water and non-water components $\left(K_{\mathrm{I}}=K_{\mathrm{I}}^{\mathrm{W}}+K_{\mathrm{I}}^{\mathrm{nw}} ;\right.$ Baker and Smith, 1982; Smith and Baker, $1978 \mathrm{a}, b$ ), where $K_{\mathrm{I}}^{\mathrm{nw}}$ is controlled by the concentrations of phytoplankton, colored dissolved organic matter (CDOM), and non-algal particles (NAP). In the open ocean where CDOM and NAP covary with phytoplankton (Morel and Prieur, 1977), $K_{\mathrm{I}}$ can be related to $C$ as follows:

$K_{\mathrm{I}}=K_{\mathrm{I}}^{\mathrm{w}}+k_{\mathrm{c}} \cdot C$,

where $k_{c}$ is a function of the solar zenith angle, the specific absorption and backscattering coefficients of phytoplankton, and the relationship between phytoplankton, CDOM, and NAP. Because pure water and phytoplankton attenuate light, $K_{\mathrm{I}}^{\mathrm{w}}$ and $k_{\mathrm{c}}$ should be greater than zero.

To calculate how $\mathrm{NCP}(0, \mathrm{MLD})$ varies as a function of $C$, we examine its first $\left(\frac{\mathrm{dNCP}(0, \mathrm{MLD})}{\mathrm{d} C}\right)$ and second $\left(\frac{d^{2} \mathrm{NCP}(0, \mathrm{MLD})}{\mathrm{d} C^{2}}\right)$ derivatives with respect to $C$ based on Eqs. (8) and (10):

$$
\begin{aligned}
& \frac{\mathrm{dNCP}(0, \mathrm{MLD})}{\mathrm{d} C}=N_{m} \cdot \mu_{\max } \\
& \cdot \frac{K_{\mathrm{I}}^{\mathrm{w}} \cdot I_{m}(0, \mathrm{MLD})+k_{\mathrm{c}} \cdot C \cdot \mathrm{MLD} \cdot I_{m}(\mathrm{MLD})}{K_{\mathrm{I}}^{\mathrm{w}}+k_{\mathrm{c}} \cdot C} \\
& -r_{\mathrm{HR}} \cdot \mathrm{MLD}, \\
& \frac{d^{2} \mathrm{NCP}(0, \mathrm{MLD})}{\mathrm{d} C^{2}}=N_{m} \cdot k_{\mathrm{c}} \cdot \frac{\mu_{\max }}{K_{\mathrm{I}}} \\
& \cdot\left\{\frac{2 \cdot K_{\mathrm{I}}^{\mathrm{w}}}{K_{\mathrm{I}}} \cdot\left(\mathrm{MLD} \cdot I_{m}(\mathrm{MLD})-I_{m}(0, \mathrm{MLD})\right)\right. \\
& \left.-\frac{k_{\mathrm{c}} \cdot C \cdot I_{m}(\mathrm{MLD})^{2} \cdot \mathrm{MLD}^{2} \cdot k_{m}^{\mathrm{I}}}{I_{0} \cdot e^{-K_{\mathrm{I}} \cdot \mathrm{MLD}}}\right\},
\end{aligned}
$$

when MLD $>0, I_{m}(0, \mathrm{MLD})>\mathrm{MLD} \cdot I_{m}(\mathrm{MLD})$ :

$$
\begin{aligned}
& I_{m}(0, \mathrm{MLD})=\int_{0}^{\mathrm{MLD}} \frac{I_{0} \cdot e^{-K_{\mathrm{I}} \cdot z}}{I_{0} \cdot e^{-K_{\mathrm{I}} \cdot z}+k_{m}^{\mathrm{I}}} \mathrm{d} z \\
& \quad>\int_{0}^{\mathrm{MLD}} \frac{I_{0} \cdot e^{-K_{\mathrm{I}} \cdot \mathrm{MLD}}}{I_{0} \cdot e^{-K_{\mathrm{I}} \cdot \mathrm{MLD}}+k_{m}^{\mathrm{I}}} \mathrm{d} z=\mathrm{MLD} \cdot I_{m}(\mathrm{MLD}) .
\end{aligned}
$$

The detailed derivation of Eqs. (11)-(12) can be found in the Supplement. Substituting the inequality (13) into Eq. (12) gives $\frac{d^{2} \mathrm{NCP}(0, \mathrm{MLD})}{\mathrm{d} C^{2}}<0$, which suggests that $\frac{\mathrm{dNCP}(0, \mathrm{MLD})}{\mathrm{d} C}$ decreases with increasing $C$. Because increasing $C$ decreases light availability due to shelf-shading, NPP $(0, M L D)$ saturates with increasing $C$. Thus, $\mathrm{NCP}(0, \mathrm{MLD})$ will reach an asymptote of $\lim _{C \rightarrow \infty}\left(\frac{\mathrm{dNCP}(0, \mathrm{MLD})}{\mathrm{d} C}\right)=-r_{\mathrm{HR}} \cdot \mathrm{MLD}<$ 0 because $\operatorname{HR}(0, M L D)$ linearly increases with increasing $C$, while $\mathrm{NPP}(0, \mathrm{MLD})$ plateaus (Fig. 2). Additionally, because $\mathrm{NCP}(0, \mathrm{MLD})$ must be nil when there is no autotrophic biomass $\left(\left.\operatorname{NCP}(0, \mathrm{MLD})\right|_{C=0}=0\right)$, $\lim _{C \rightarrow 0}\left(\frac{\mathrm{dNCP}(0, \mathrm{MLD})}{\mathrm{d} C}\right)$ must be greater than zero; otherwise the ecosystem would be net heterotrophic, which is unachievable without an allochthonous source of organic matter. $\lim _{C \rightarrow 0}\left(\frac{\mathrm{dNCP}(0, \mathrm{MLD})}{\mathrm{d} C}\right)>0$ and $\lim _{C \rightarrow \infty}\left(\frac{\mathrm{dNCP}(0, \mathrm{MLD})}{\mathrm{d} C}\right)=-r_{\mathrm{HR}}$. $\mathrm{MLD}<0$ suggest the existence of $\left.\frac{\mathrm{dNCP}(0, \mathrm{MLD})}{\mathrm{d} C}\right|_{C=C^{*}}=0$, 


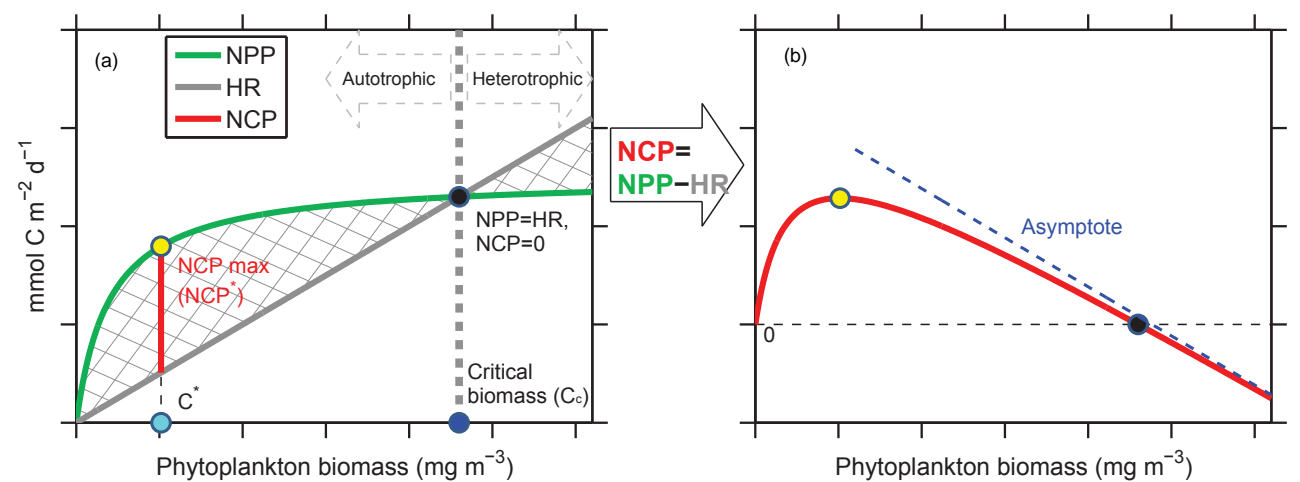

Figure 2. Relationship between net primary production (NPP), heterotrophic respiration (HR), net community production (NCP), and phytoplankton biomass concentration $(C)$ for a given mixed layer depth (MLD). The hatched area in panel (a) represents NCP. The yellow dot represents the maximal $\mathrm{NCP}\left(\mathrm{NCP}^{*}\right)$ obtainable for a given MLD, with the corresponding phytoplankton biomass concentration $\left(C^{*}\right)$ denoted with a cyan dot. NCP on the right of the yellow dot decreases with $C$ due to self-shading. The black dot represents depth-integrated $\mathrm{NCP}=0$ (i.e., $\mathrm{NPP}=\mathrm{HR}$ ), with the corresponding phytoplankton biomass concentration defined as critical biomass $\left(C_{\mathrm{c}}\right)$ and denoted with a blue dot. Ecosystems on the left and right of this threshold are net autotrophic and heterotrophic, respectively. The asymptote (dashed blue line) in panel (b) represents a system dominated by heterotrophic respiration (i.e., NCP $\approx \mathrm{HR} \gg \mathrm{NPP}$ ).

where $C^{*}$ corresponds to an autotrophic biomass concentration that maximizes $\mathrm{NCP}(0, \mathrm{MLD})$, i.e., $\mathrm{NCP}^{*}$.

The dependence of $\mathrm{NCP}(0, \mathrm{MLD})$ on $C$ can be conceptually understood in the following way. Given a water column with sufficient nutrients, the critical depth $Z_{\mathrm{c}}$ and compensation depth $Z_{\mathrm{p}}$ are expected to shoal as $C$ increases. When $C$ is low, $\operatorname{NCP}(0, M L D)$ increases with $C$ because of its greater impact on $\operatorname{NPP}(0, M L D)$ than on $\operatorname{HR}(0$, MLD). As $C$ further increases, the increase in $\operatorname{NPP}(0$, MLD) with $C$ slows because of light attenuation (i.e., $K_{\mathrm{I}}$ ). There is therefore a $C^{*}$ that maximizes the difference between NPP $(0$, MLD $)$ and $\mathrm{HR}(0, \mathrm{MLD})$ leading to $\mathrm{NCP}^{*}$ (Fig. 2). Beyond this point $\left(C^{*}\right)$, further increasing $C$ will cause self-shading and limit photosynthesis in the deep part of the mixed layer as a result decreasing $\operatorname{NCP}(0, \mathrm{MLD})$. Beyond a critical biomass $\left(C_{\mathrm{c}}\right)$, the ecosystem becomes net heterotrophic. Without an allochthonous source of organic carbon, this is only transiently sustainable.

\subsection{Mixed layer depth and compensation depth}

By definition, if NCP(MLD) is less than zero (i.e., net heterotrophy at the bottom of the mixed layer), the MLD must be deeper than $Z_{\mathrm{p}}\left(\mathrm{MLD}>Z_{\mathrm{p}}\right.$ ) and vice versa. To determine the sign of NCP(MLD), we substitute inequality (13) into Eq. (11). According to the inequality presented in Eq. (13), $\frac{K_{\mathrm{I}}^{\mathrm{w}} \cdot I_{m}(0, \mathrm{MLD})+k_{\mathrm{c}} \cdot C \cdot \mathrm{MLD} \cdot I_{m}(\mathrm{MLD})}{K_{\mathrm{I}}^{\mathrm{w}}+k_{\mathrm{c}} \cdot C}$ in Eq. (11) must be greater than $\frac{K_{\mathrm{I}}^{\mathrm{w}} \cdot \mathrm{MLD} \cdot I_{m}(\mathrm{MLD})+k_{\mathrm{c}} \cdot C \cdot \mathrm{MLD} \cdot I_{m}(\mathrm{MLD})}{K_{\mathrm{I}}^{\mathrm{w}}+k_{\mathrm{c}} \cdot C}$, which is equal to MLD $\cdot I_{m}(\mathrm{MLD})$. After simple rearrangements, the substitution of inequality (13) into Eq. (11) leads to

$$
\begin{aligned}
& \frac{\mathrm{dNCP}(0, \mathrm{MLD})}{\mathrm{d} C}>\mathrm{MLD} \\
& \cdot\left(N_{m} \cdot I_{m}(\mathrm{MLD}) \cdot \mu_{\max }-r_{\mathrm{HR}}\right)
\end{aligned}
$$

$$
=\frac{\mathrm{MLD}}{C} \cdot \mathrm{NCP}(\mathrm{MLD}) .
$$

The inequality in Eq. (14) in turn suggests that when $\operatorname{NCP}(0, M L D)$ is maximized $\left(\frac{\mathrm{dNCP}(0, \mathrm{MLD})}{\mathrm{dC}}=0\right)$, $\operatorname{NCP}(M L D)$ is negative (net heterotrophic) and hence the MLD is deeper than $Z_{\mathrm{p}}\left(\mathrm{MLD}>Z_{\mathrm{p}}\right.$ ). This counterintuitive result is attributable both to the uneven distribution of light availability in the water column (Eq. 13) and to water, which absorbs light but does not contribute to biomass accumulation. When the mixed layer is at the $Z_{\mathrm{p}}$, a slight increase in $C$ will lead to negative NCP(MLD) due to decreasing light availability at the base of the mixed layer, but it will increase NCP higher in the water column because of the increase in biomass. The increase in NCP in the shallow parts of the mixed layer therefore overcompensates for the net heterotrophy at the bottom of the mixed layer, thus maximizing the depth-integrated NCP. If light were uniformly distributed in the water column, i.e., $I_{m}(0, \mathrm{MLD})=\mathrm{MLD} \cdot I_{m}(\mathrm{MLD})$, and if water did not attenuate light $\left(K_{\mathrm{I}}^{\mathrm{w}}=0\right.$ in Eq. 11), $\mathrm{MLD}=Z_{\mathrm{p}}$ would maximize $\mathrm{NCP}(0, \mathrm{MLD})$, which is consistent with Huisman and Weissing (1994). We note that in Eq. (14) the NCP profile $(\mathrm{NCP}(z))$ varies with increasing $C$, which is different from what is conceptually presented in Fig. 1. The depth-integrated NCP in Fig. 1 maximizes at the compensation depth because the NCP profile $(\operatorname{NCP}(z))$ is assumed to be invariant.

\subsection{An upper bound on carbon export}

Equations (11)-(13) delineate the conditions for an upper bound on carbon export ( $\left.\mathrm{NCP}^{*}\right)$. In order to simplify the relationship of $\mathrm{NCP}^{*}$ to MLD and temperature, we approximate 
$I_{m}(0, \mathrm{MLD})$ :

$$
\begin{aligned}
& I_{m}(0, \mathrm{MLD})=-\frac{1}{K_{\mathrm{I}}} \cdot \ln \left(1+\frac{I_{0}}{I_{0}+k_{m}^{\mathrm{I}}} \cdot\left(e^{-K_{\mathrm{I}} \cdot \mathrm{MLD}}-1\right)\right) \\
& \approx-\frac{1}{K_{\mathrm{I}}} \cdot \ln \left(1-I_{m}(0)\right)
\end{aligned}
$$

where $I_{m}(0)=\frac{I_{0}}{I_{0}+k_{m}^{I}}$. Based on Eq. (15), $\mathrm{NCP}(0, \mathrm{MLD})$ in Eq. (8) can be approximated as

$\operatorname{NCP}(0, \operatorname{MLD})=C \cdot \operatorname{MLD} \cdot\left(\frac{1}{K_{\mathrm{I}} \cdot \operatorname{MLD}} \cdot \mu^{*}-r_{\mathrm{HR}}\right)$,

where $\mu^{*}=-\ln \left(1-I_{m}(0)\right) \cdot N_{m} \cdot \mu_{\max }$. To evaluate the approximation accuracy of Eq. (15), we compare the upper bounds estimated from Eq. (16) and the original model (Eqs. 8-10). Our comparison suggests that the approximation of Eq. (15) is accurate for the estimation of $\mathrm{NCP}^{*}$ under most conditions (Fig. 3).

We first need to derive the $C^{*}$ that maximizes $\operatorname{NCP}(0, \mathrm{MLD})$ (i.e., $\left.\mathrm{NCP}^{*}\right)$ in Eq. (16). $C^{*}$ can be solved from the first derivative of $\operatorname{NCP}(0, M L D)$ in $\mathrm{Eq}$. (16) with respect to $C$ :

$$
\begin{aligned}
& \left.\frac{\mathrm{dNCP}(0, \mathrm{MLD})}{\mathrm{d} C}\right|_{\mathrm{NCP}(0, \mathrm{MLD})=\mathrm{NCP}^{*}} \\
& =\mu^{*} \cdot \frac{K_{\mathrm{I}}^{\mathrm{W}}}{\left(k_{\mathrm{c}} \cdot C^{*}+K_{\mathrm{I}}^{\mathrm{w}}\right)^{2}}-\mathrm{MLD} \cdot r_{\mathrm{HR}}=0
\end{aligned}
$$

and therefore

$C^{*}=\frac{1}{k_{\mathrm{c}}} \cdot\left[-K_{\mathrm{I}}^{\mathrm{w}}+\sqrt{\frac{\mu^{*} \cdot K_{\mathrm{I}}^{\mathrm{W}}}{\mathrm{MLD} \cdot r_{\mathrm{HR}}}}\right]$.

Equation (18) decreases with MLD. As $C^{*}$ is positive $\left(C^{*} \geq\right.$ 0 ) and cannot go to infinity $\left(C^{*} \leq C_{\max }^{*}\right)$, MLD should satisfy $\mathrm{MLD}_{C_{\max }^{*}} \leq \mathrm{MLD} \leq \frac{\mu^{*}}{r_{\mathrm{HR}} \cdot K_{\mathrm{I}}^{\mathrm{w}}}$, where $\mathrm{MLD}_{C_{\max }^{*}}$ represents the MLD corresponding to the maximum achievable autotroph biomass concentration $\left(C_{\max }^{*}\right)$ in the surface ocean. The $\mathrm{NCP}^{*}$ model for $0 \leq \mathrm{MLD}<\mathrm{MLD}_{C_{\max }^{*}}$ is not discussed here because we do not have data with very shallow MLD to constrain and evaluate the model. The derivation of the model is, however, presented in the Supplement. Substituting $C^{*}$ from Eq. (18) into (16) results in

$\sqrt{\mathrm{NCP}^{*}}=a_{2} \cdot \sqrt{-\ln \left(1-I_{m}(0)\right)}+a_{1} \cdot \sqrt{\mathrm{MLD}}$,

where $a_{1}=-\sqrt{\frac{K_{\mathrm{I}}^{\mathrm{W}} \cdot r_{\mathrm{HR}}}{k_{\mathrm{c}}}}$ and $a_{2}=\sqrt{\frac{N_{m} \cdot \mu_{\max }}{k_{\mathrm{c}}}}$. Constants $a_{1}$ and $a_{2}$ are functions of $r_{\mathrm{HR}}$ and $\mu_{\text {max }}$, respectively, which are generally modeled to increase with temperature $(T)$ (Eppley, 1972; Rivkin and Legendre, 2001):

$\mu_{\max }=\mu_{\max }^{0} \cdot e^{P_{t} \cdot T}$,

$r_{\mathrm{HR}}=r_{\mathrm{HR}}^{0} \cdot e^{B_{t} \cdot T}$,

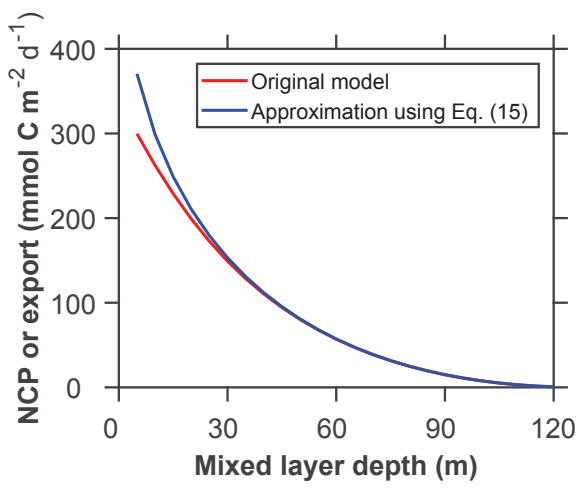

Figure 3. Upper bounds derived using the original and approximated models. The upper bound for the original model (Eqs. 8 10 ) is estimated through a nonlinear optimization approach. The upper bound for the approximated model is calculated analytically from Eq. (19). The models use the constants listed in Table 1 and $I_{\mathrm{m}}(0)=0.9$. Decreasing $I_{\mathrm{m}}(0)$ and increasing $r_{\mathrm{HR}}$ results in greater discrepancies between the original and approximated models in regions with shallow mixed layers.

where $P_{t}$ and $B_{t}$ are constants, and $\mu_{\max }^{0}$ and $r_{\mathrm{HR}}^{0}$ are the maximum growth rate and heterotrophic respiration ratio for $T=0{ }^{\circ} \mathrm{C}$, respectively. $P_{t}$ is commonly assumed to equal 0.0663 (Eppley, 1972). Substituting Eqs. (20a) and (20b) into Eq. (19) yields

$$
\begin{aligned}
& \sqrt{\mathrm{NCP}^{*}}=a_{4} \cdot \sqrt{e^{P_{t} \cdot T}} \cdot \sqrt{-\ln \left(1-I_{m}(0)\right)} \\
& +a_{3} \cdot \sqrt{e^{B_{t} \cdot T}} \cdot \sqrt{\mathrm{MLD}},
\end{aligned}
$$

where $a_{3}=-\sqrt{\frac{r_{\mathrm{HR}}^{0} \cdot K_{\mathrm{I}}^{\mathrm{w}}}{k_{\mathrm{c}}}}$ and $a_{4}=\sqrt{\frac{\mu_{\mathrm{max}}^{0} \cdot N_{m}}{k_{\mathrm{c}}}}$.

\subsection{Comparison to observations}

\subsubsection{Data products}

We assess the performance of our modeled upper bound on carbon export using a global dataset of MLD, PAR, sea surface temperature (SST), $\mathrm{O}_{2} /$ Ar-derived NCP, and export production derived from sediment traps and ${ }^{234} \mathrm{Th}$ (see the Supplement). MLD was derived from global Argo profiles (Global Ocean Data Assimilation Experiment; http://www. usgodae.org/) and CTD casts (National Oceanographic Data Center; https://www.nodc.noaa.gov/). PAR was downloaded from the NASA ocean color website (https://oceancolor.gsfc. nasa.gov/). The NCP estimates are based on a compilation of $\mathrm{O}_{2} / \mathrm{Ar}$ measurements from $\mathrm{Li}$ and Cassar (2016), Li et al. (2016), Shadwick et al. (2015), and Martin et al. (2013). The POC export production estimates were obtained from the recently compiled dataset of Mouw et al. (2016). These estimates were adjusted to reflect a flux at the base of the mixed layer using the Martin curve of organic carbon attenuation with depth (Martin et al., 1987). The constants $k_{\mathrm{c}}$ and $K_{\mathrm{I}}^{\mathrm{W}}$ 

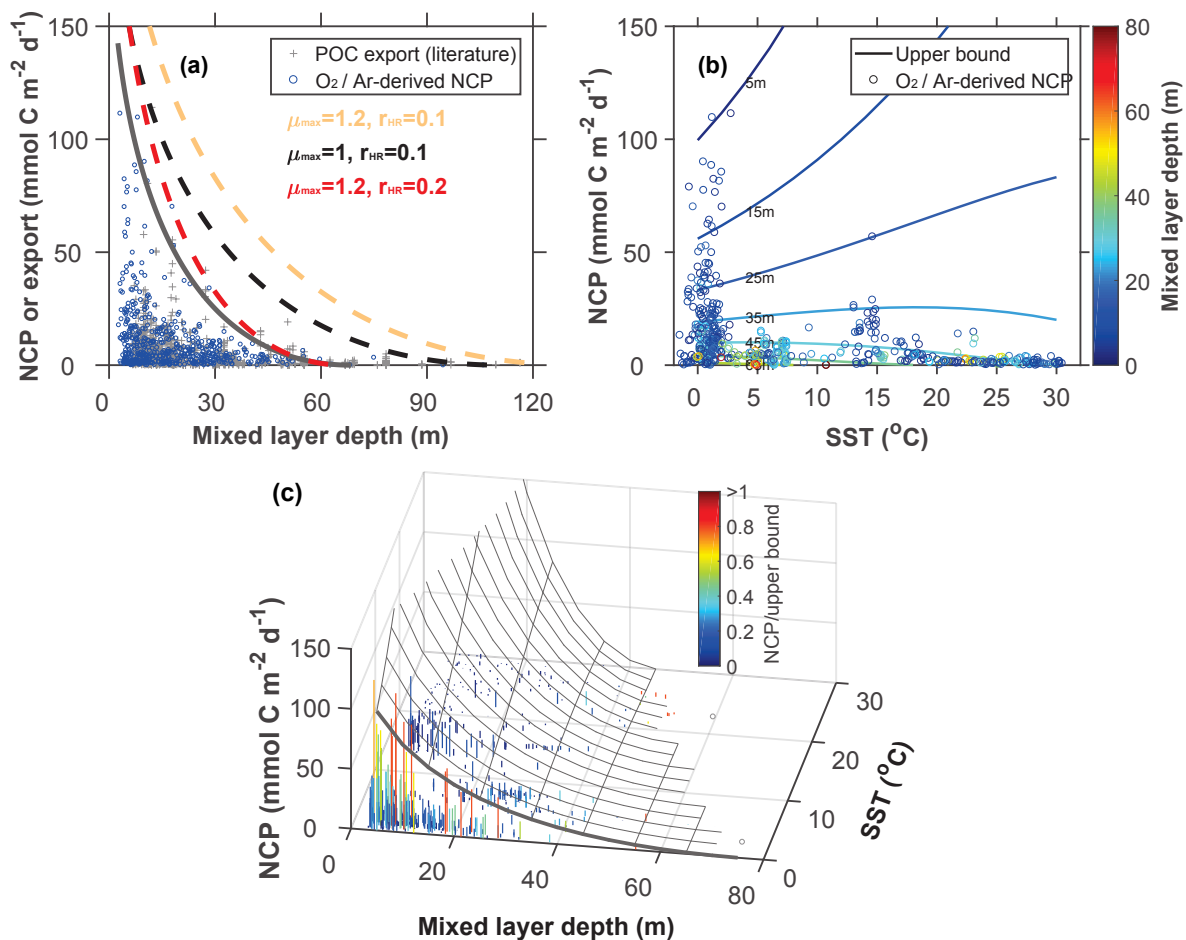

Figure 4. Modeled upper bound on carbon export production compared to field observations as a function of mixed layer depth (MLD) and sea surface temperature (SST). (a) The thick gray line represents the upper bound fitted to the net community production (NCP) data. Dashed lines represent the upper bounds calculated using parameters available in the literature (Table 1). (b) NCP as a function of SST with isopleths of constant upper bounds color coded for MLD. NCP observations are color coded with MLD. (c) Surface representing the envelope of the modeled upper bound of carbon export production as a function of SST and MLD. Bars represent field observations color coded with the ratio of NCP to the upper bound. Observations are based on ${ }^{234} \mathrm{Th}$ and sediment trap estimates of carbon export production and $\mathrm{O}_{2} / \mathrm{Ar}-\mathrm{derived}$ NCP. A stoichiometric ratio of $\mathrm{O}_{2} / \mathrm{C}=1.4$ was used to convert $\mathrm{NCP}$ from $\mathrm{O}_{2}$ to $\mathrm{C}$ units (Laws, 1991). To account for the effect of PAR on export production, both MLD and carbon fluxes are normalized to $-\log \left(1-I_{m}(0)\right)$ (see Eqs. 19 and 21). The temperature dependence of $r_{\mathrm{HR}}$ was modeled as $r_{\mathrm{HR}}=r_{\mathrm{HR}}^{0} \cdot e^{0.08 \cdot T}$.

in Eq. (10) were derived assuming a carbon to chlorophyll $a$ ratio of 90 (Arrigo et al., 2008) and an empirical linear relationship between $K_{\mathrm{I}}$ and chlorophyll $a$ concentration (see Fig. S3 in the Supplement) calculated based on the NOMAD dataset (Werdell and Bailey, 2005). The $k_{m}^{\mathrm{I}}$ value was set at 4.1 einstein $\mathrm{m}^{-2} \mathrm{~d}^{-1}$ following Behrenfeld and Falkowski (1997). In our estimation of the upper bound on carbon export, we set $N_{m}$ to 1 in the $\mathrm{NCP}^{*}$ calculations.

\subsubsection{Results and discussion}

Overall, we find that $\mathrm{NCP}^{*}$ calculated using published parameters (Table 1) does a good job of enveloping the carbon export observations reported in the literature (Fig. 4a). Samples on the NCP* envelope (upper bound) are likely regulated by light availability. Conversely, points below the upper bound may be nutrient limited. As expected, NCP* increases with $\mu_{\max }$ and decreases with $r_{\mathrm{HR}}$. Model parameters $a_{1}=-1.78$ and $a_{2}=14.75$ (Eq. 19) provide the best fit to the upper bound of $\mathrm{O}_{2} / \mathrm{Ar}$ NCP as a function of MLD. When compared to parameters available in the literature (Ta- ble 1), we find the best fit to our modeled upper bound when using $\mu_{\max }$ and $r_{\mathrm{HR}}$ of 1.2 and $0.2 \mathrm{~d}^{-1}$, respectively. When accounting for the effect of $T$ on $\mu_{\max }$ and $r_{\mathrm{HR}}$, model constants $a_{3}=-1.53$ and $a_{4}=13.39$ (Eq. 21) best fit the upper bound on $\mathrm{O}_{2}$ / Ar NCP, SST, and MLD observations.

Our results show that $\mathrm{NCP}^{*}$ decreases faster with increasing MLD in warmer waters (Fig. $4 \mathrm{~b}$ and c) because the term $a_{3} \cdot \sqrt{e^{B_{t} \cdot T}}$ in Eq. (21) is negative and negatively correlated with $T$. This temperature effect contributes to part of the relationship between export production and MLD in Fig. 4a. Interestingly, NCP* increases with $T$ in colder waters and shallow mixed layers (Fig. 4c). This is because $\mathrm{NCP}^{*}$ reflects the balance between productivity $\left(a_{4} \cdot \sqrt{e^{P_{t} \cdot T}}\right.$. $\left.\sqrt{-\ln \left(1-I_{m}(0)\right)}\right)$ and heterotrophic respiration $\left(a_{3} \cdot \sqrt{e^{B_{t} \cdot T}}\right.$. $\sqrt{\mathrm{MLD}})$. In a shallow, cold mixed layer, the change in productivity with $T\left(\frac{\mathrm{d}\left(a_{4} \cdot \sqrt{e^{P_{t} \cdot T}} \cdot \sqrt{-\ln \left(1-I_{m}(0)\right)}\right)}{\mathrm{d} T}=\frac{P_{t}}{2} \cdot a_{4} \cdot \sqrt{e^{P_{t} \cdot T}}\right.$. $\left.\sqrt{-\ln \left(1-I_{m}(0)\right)}\right)$ is greater than that of heterotrophic respiration $\left(\frac{\mathrm{d}\left(a_{3} \cdot \sqrt{e^{B_{t} \cdot T}} \cdot \sqrt{\mathrm{MLD}}\right)}{\mathrm{d} T}=\frac{B_{t}}{2} \cdot a_{3} \cdot \sqrt{e^{B_{t} \cdot T}} \cdot \sqrt{\mathrm{MLD}}\right)$. These results could explain part of the variability in the relationship 
Table 1. Value or range of values with references for the parameters used in the model.

\begin{tabular}{lll}
\hline Parameter & Range or value & Reference \\
\hline$K_{\mathrm{I}}^{\mathrm{W}}$ & 0.09 & Werdell and Bailey (2005) \\
$k_{\mathrm{c}}$ & 0.03 & Werdell and Bailey (2005) \\
Carbon to chlorophyll ratio & 90 & Arrigo et al. (2008) \\
$k_{\mathrm{m}}^{I}$ & 4.1 einstein $\mathrm{m}^{-2} \mathrm{~d}^{-1}$ & Behrenfeld and Falkowski (1997) \\
$P_{\mathrm{t}}$ & 0.0663 & Eppley (1972) \\
$B_{\mathrm{t}}$ & 0.08 & Rivkin and Legendre (2001), López-Urrutia et al. (2006) \\
$\mu_{\mathrm{max}}$ & $1 \mathrm{~d}^{-1}, 1.2 \mathrm{~d}^{-1}$ & Laws et al. (2000), Eppley (1972) \\
$r_{\mathrm{HR}}$ & $0.1 \mathrm{~d}^{-1}, 0.2 \mathrm{~d}^{-1}$ & Laws et al. (2000), Mitchell et al. (1991) \\
\hline
\end{tabular}

between NCP and SST reported in previous studies ( $\mathrm{Li}$ and Cassar, 2016). Our NCP* model does not perform as well in warmer, deep mixed layers where high variability in export ratio maxima have also been reported (Cael and Follows, 2016). This may stem from uncertainties in observations, the differing relationship between $T, \mu_{\max }$, and $r_{\mathrm{HR}}$ at high temperature, and/or violations of our assumptions (see the "Caveats and limitations" section).

Several recent studies have explored the relationship of NCP to oceanic parameters based on various statistical approaches (Cassar et al., 2015; Chang et al., 2014; Huang et al., 2012; Li and Cassar, 2016; Li et al., 2016). Our model can shed some light onto the mechanisms driving some of these patterns. To that end, we substitute Eq. (9) into Eq. (8):

$$
\begin{aligned}
& \operatorname{NCP}(0, \mathrm{MLD})=C \cdot M L D \\
& \quad \cdot\left(-\frac{N_{m} \cdot \mu_{\mathrm{max}}}{K_{\mathrm{I}} \cdot \mathrm{MLD}} \cdot \ln \left(\frac{I_{0} \cdot e^{-K_{\mathrm{I}} \cdot \mathrm{MLD}}+k_{m}^{\mathrm{I}}}{I_{0}+k_{m}^{\mathrm{I}}}\right)-r_{\mathrm{HR}}\right) .
\end{aligned}
$$

Rearranging Eq. (22) results in

$$
\begin{aligned}
& \mathrm{NCP}_{\mathrm{B}}=\frac{\mathrm{NCP}(0, \mathrm{MLD})}{C \cdot \mathrm{MLD}}=-\frac{\ln \left(\frac{I_{0} \cdot e^{-K_{\mathrm{I}} \cdot \mathrm{MLD}}+k_{m}^{\mathrm{I}}}{I_{0}+k_{m}^{I}}\right)}{I_{0} \cdot\left(1-e^{-K_{\mathrm{I}} \cdot \mathrm{MLD}}\right)} \\
& \cdot N_{m} \cdot \mu_{\max } \cdot \mathrm{PAR}_{\mathrm{ML}}-r_{\mathrm{HR}}
\end{aligned}
$$

where $\mathrm{NCP}_{\mathrm{B}}$ is the biomass-normalized volumetric NCP, $\mathrm{PAR}_{\mathrm{ML}}$ is the average PAR in the mixed layer $\left(\mathrm{PAR}_{\mathrm{ML}}=\right.$ $\left.\frac{1-e^{-K_{\mathrm{I}} \cdot \mathrm{MLD}}}{K_{\mathrm{I}} \cdot \mathrm{MLD}} \cdot I_{0}\right)$, and $-\frac{\ln \left(\frac{I_{0} \cdot e^{-K_{\mathrm{I}} \cdot \mathrm{MLD}_{+} \mathrm{I}}}{I_{0}+k_{m}^{1}}\right)}{I_{0} \cdot\left(1-e^{-K_{\mathrm{I}} \cdot \mathrm{MLD}}\right)} \cdot N_{m} \cdot \mu_{\mathrm{max}}$ and $-r_{\mathrm{HR}}$ correspond to the slope and offset, respectively. The scatter in the relationship between chlorophyll-normalized volumetric NCP and PAR $\mathrm{RL}_{\mathrm{ML}}$, as reported in previous studies (Bender et al., 2016), can likely be explained by the effect of temperature and the availability of nutrients and light (among other properties) on the slope and offset of Eq. (23). Equation (22) can also be reorganized to assess how environmental conditions may impact the export ratio (ef):

ef $=\frac{\operatorname{NCP}(0, \mathrm{MLD})}{\operatorname{NPP}(0, \mathrm{MLD})}=1-\frac{K_{\mathrm{I}} \cdot \mathrm{MLD}}{-\ln \left(\frac{I_{0} \cdot e^{-K_{\mathrm{I}} \cdot \mathrm{MLD}}+k_{m}^{\mathrm{I}}}{I_{0}+k_{m}^{1}}\right)}$

$$
\cdot \frac{1}{N_{m}} \cdot \frac{r_{\mathrm{HR}}}{\mu_{\max }}
$$

where $\frac{r_{\mathrm{HR}}}{\mu_{\max }}$ is proportional to $e^{\left(B_{t}-P_{t}\right) \cdot T}$. Equation (24) is consistent with multiple studies that predict decreasing ef with increasing temperature (Cael and Follows, 2016; Dunne et al., 2005; Henson et al., 2011; Laws et al., 2000; Li and Cassar, 2016). In fact, Eq. (5) of Cael and Follows (2016) can easily be derived from Eq. (24) (see the Supplement). Equation (24) also highlights the fact that a multitude of factors may confound the dependence of ef on temperature (including varying MLD, light attenuation, and availability of nutrients and light). This again may explain some of the conflicting observations recently reported in the literature (e.g., Maiti et al., 2013); the effect of temperature may be masked by changes in community composition (Britten et al., 2017; Henson et al., 2015). One therefore needs to account or correct for the multitude of confounding factors when predicting the effect of a given environmental condition (e.g., temperature, mineral ballast, and NPP) on the export ratio.

\section{Spatial distribution of the upper bound on carbon export}

We estimate the global distribution of the upper bound of carbon export using Eq. (19) and climatological monthly MLD and PAR. In general, NCP* is high in low latitudes and low in the North Atlantic and Antarctic Circumpolar Current (ACC) in the Southern Ocean (Fig. 5a). As expected, this spatial pattern is controlled by MLD (see Fig. S1). Satellite-derived estimates of NCP (Li and Cassar, 2016) are approximately $10 \%$ of global $\mathrm{NCP}^{*}$, reflecting the high degree of nutrient limitation in the oceans. We also derive a global $\mathrm{NCP}^{*}$ map using Eq. (21) and find that the global $\mathrm{NCP}^{*}$ estimate is very sensitive to the temperature dependence of $r_{\mathrm{HR}}$. For example, decreasing the $B_{t}$ in $r_{\mathrm{HR}}=r_{\mathrm{HR}}^{0} \cdot e^{B_{t} \cdot T}$ from 0.11 to 0.08 (as used in Rivkin and Legendre, 2001, and López-Urrutia et al., 2006) increases the global $\mathrm{NCP}^{*}$ budget by a factor of 2.4. Large differences in $\mathrm{NCP}^{*}$ in low latitudes in large part explain this change. In light of the large uncertainties in the relationship between $r_{\mathrm{HR}}$ and $T$ (Cael and Follows, 2016; 

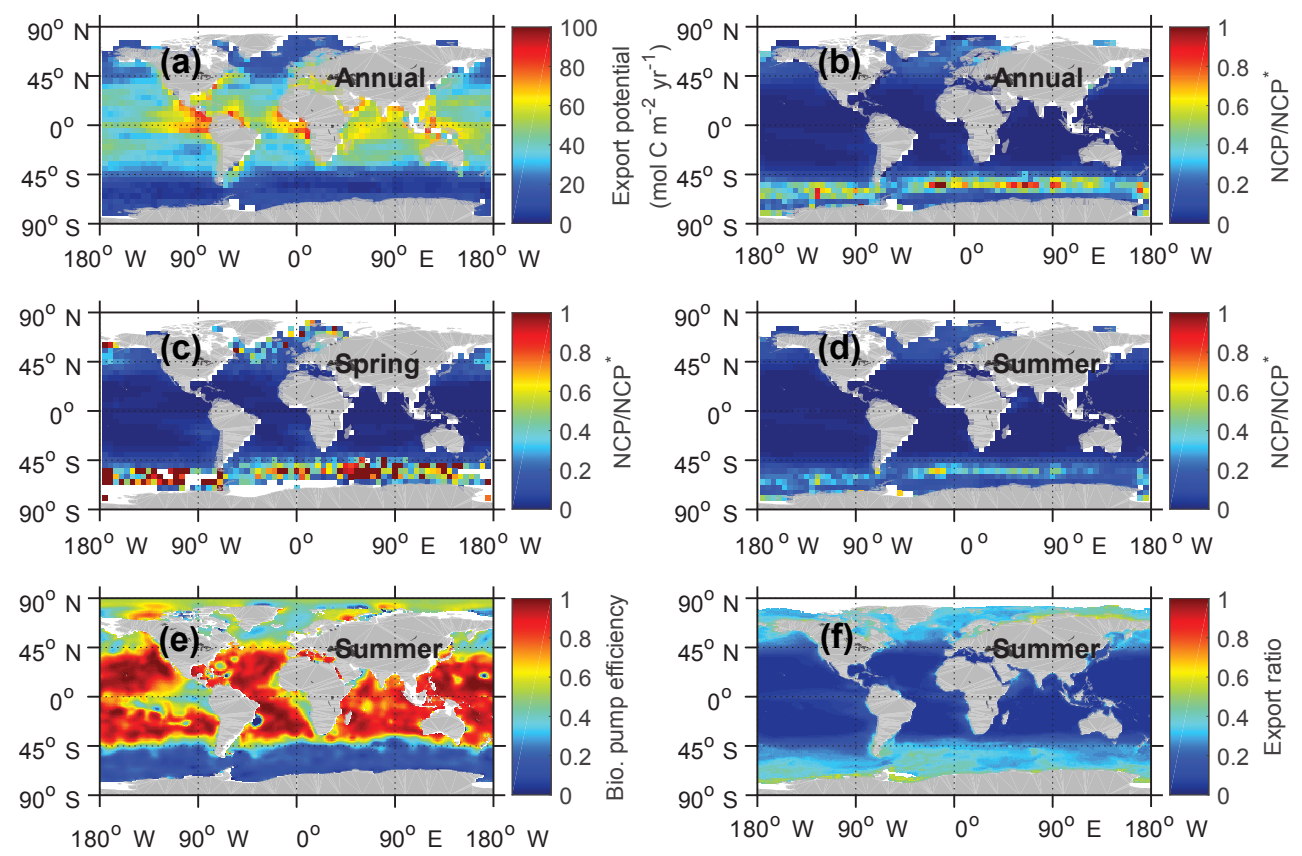

Figure 5. (a) Modeled upper bound on carbon export derived from Eq. (19), (b-d) ratios of satellite export production estimates to the upper bound on carbon export, (e) biological pump efficiency calculated as the difference in nutrient concentrations between surface and depth normalized to nutrient concentrations at depth (Sarmiento and Gruber, 2006; nitrate concentration from the World Ocean Atlas at https://www.nodc.noaa.gov/OC5/woa13/), and (f) export ratio derived from Dunne et al. (2005). "Annual" represents the annually integrated value. Spring and summer represent the average value in spring and summer, respectively. In the Northern Hemisphere, the spring and summer seasons are defined as March-May and June-August, respectively. In the Southern Hemisphere, the spring and summer seasons are defined as September-November and December-February, respectively.

López-Urrutia et al., 2006), we hereafter only discuss NCP* estimates derived from Eq. (19).

To estimate how close export production is to its upper bound, we calculate the ratio of export production to $\mathrm{NCP}^{*}$ $\left(f_{\mathrm{pt}}\right)$. Low $f_{\mathrm{pt}}$ regimes represent ecosystems likely regulated by nutrient availability (i.e., ecosystems that have not reached their full export potential based on MLD and surface PAR). As expected, low-latitude and subtropical regions have low $f_{\mathrm{pt}}$ (Fig. 5b). High $f_{\mathrm{pt}}$ regimes represent ecosystems that have reached their full light potential and are therefore less likely to respond to nutrient addition because of light limitation (e.g., the North Atlantic and ACC; Fig. 5b). In these regions, especially the subantarctic region, $f_{\mathrm{pt}}$ is high in the spring (Fig. 5c) and decreases in the summer (Fig. 5d), suggesting that export production is likely co-limited by nutrient and light availability. This may in part explain the lower response to iron fertilization in the subantarctic region where substantial increases in surface chlorophyll were only observed in regions with shallower mixed layers (Boyd et al., 2007, 2000; de Baar et al., 2005).

Also shown in Fig. 5 are the biological pump efficiency and export ratios (Fig. 5e and f, respectively). These various proxies reflect different components of the biological pump. Whereas $f_{\mathrm{pt}}$ reflects the export potential based on current MLD and light availability, the biological pump efficiency reflects the potential as derived from nutrient distribution in the oceans and estimated from the extent of nutrient removal from the surface ocean (Sarmiento and Gruber, 2006) or the proportion of regenerated nutrients at depth (Ito and Follows, 2005). A revised estimate of the global biological pump efficiency, estimated based on the proportion of regenerated to total nutrients (preformed + regenerated) at depth, is around 30-35\% (Duteil et al., 2013). The ef ratio, however, describes how much of production is exported as opposed to recycled in the surface (Dunne et al., 2005). Ultra-oligotrophic subtropical waters have a low export ratio and a strong biological pump efficiency with exhaustion of nutrients at the ocean surface; they have therefore not reached their full light potential (low $f_{\mathrm{pt}}$ ) because of the strong stratification and nutrient limitation. The seasonal pattern of $f_{\mathrm{pt}}$ in the subantarctic region suggests that low biological pump efficiency is the result of light limitation in the austral spring and nutrient (likely Fe) and light limitation in the austral summer.

\section{Caveats and limitations}

There are a multitude of uncertainties, simplifications, and approximations in our model and field observations. Among others, these include the following. 
- In our study, we used a model that builds on Sverdrup's critical depth hypothesis. There are competing hypotheses to explain phytoplankton bloom phenology (timing and intensity), including the "dilution recoupling hypothesis" or "disturbance recovery hypothesis" (Behrenfeld, 2010; Boss and Behrenfeld, 2010) and the "critical turbulence hypothesis" (Brody and Lozier, 2015; Huisman et al., 1999; Taylor and Ferrari, 2011). In the case of top-down control, any respiratory grazing loss not accounted for by our loss term would behave as a system not reaching its full light potential $\left(\mathrm{NCP}^{*}\right)$. Conversely, any grazing loss associated with export (e.g., rapidly sinking fecal pellets and other zooplankton-mediated export pathways) would minimize respiratory losses, thereby bringing NCP closer to its upper bound based on light availability. These opposing effects are beyond the scope of this study but could be modeled, especially as we learn more about their impacts on carbon fluxes through new efforts such as the NASA EXPORTS program (Siegel et al., 2016). See also the point below on mixing vs. mixed layer depth.

- Phytoplankton biomass concentration $(C)$ may vary with depth in the mixed layer, especially for water columns experiencing varying degrees of turbulent mixing. In addition, MLD is not always the best proxy for light availability with the mixing layer in some cases deviating from the mixed layer (Franks, 2015; Huisman et al., 1999). The factors defining the MLD also vary in different oceanic regions.

- For simplicity, we model the dependence of photosynthesis on irradiance assuming Michaelis-Menten kinetics, which does not account for photoinhibition. More accurate models can be found in other studies (Platt et al., 1980). Due to optional absorption, $K_{\mathrm{I}}$ also varies with depth in the mixed layer. Additionally, the linear relationship between $K_{\mathrm{I}}$ and $C$ is influenced by CDOM, NAP, and other environmental factors (e.g., solar zenith angle; Gordon, 1989).

- The $\mu_{\max }$ and $r_{\text {HR }}$ values are influenced by environmental factors other than temperature, including community structure (Chen and Laws, 2017), and may vary with depth within the mixed layer (Smetacek and Passow, 1990). For these reasons, the equations relating $\mu_{\max }$ and $r_{\mathrm{HR}}$ (i.e., $B_{t}$ and $P_{t}$ ) to temperature also carry significant uncertainties (Bissinger et al., 2008; Edwards et al., 2016; Kremer et al., 2017; López-Urrutia and Morán, 2007; Rivkin and Legendre, 2001), which impacts our estimates of the upper bound on carbon export, especially in warmer regions. As in other recent studies (Cael and Follows, 2016; Cael et al., 2017; Dutkiewicz et al., 2001; Gong et al., 2015, 2017; Huisman et al., 2006; Taylor and Ferrari, 2011), we model heterotrophic respiration to vary in proportion to phy- toplankton concentration. The model could be further improved by explicitly including the concentration of heterotrophs. See the point above on the grazing effect on export with regards to $r_{\mathrm{HR}}$.

- NCP may underestimate export production when accompanied by a decrease in the inventory of organic matter in the mixed layer (see the Introduction and Eq. 2).

- Our field observations are limited, mostly focusing on the spring and summer seasons, and harbor significant uncertainties. For example, deep mixed layers can bias the $\mathrm{O}_{2} / \mathrm{Ar}$ method low if entrainment of deeper waters brings low $\mathrm{O}_{2}$ into the mixed layer. Descriptions of these uncertainties are presented in other studies (Bender et al., 2011; Cassar et al., 2014; Jonsson et al., 2013).

- Finally, our study is only relevant to the mixed layer. It does not account for productivity below the mixed layer, which can be important in some regions such as the subtropical ocean.

\section{Conclusions}

In this study, we derived a mechanistic model of an upper bound on carbon export ( $\left.\mathrm{NCP}^{*}\right)$ based on the metabolic balance between photosynthesis and respiration of the plankton community. The upper bound is a positively skewed bellshaped function of mixed layer depth (MLD). At low temperatures, the upper bound decreases with temperature if mixed layers are deep, but increases with temperature if mixed layers are shallow. We used this model to derive a global distribution of an upper bound on carbon export as a function of MLD and surface PAR, which shows high values in low latitudes and low values in high latitudes due to deep MLD. To examine how current export production compares to this upper bound in the world's oceans, we calculated the ratio of satellite export production estimates to the upper bound derived by our model. High ratios of export production to $\mathrm{NCP}^{*}$ in the North Atlantic and ACC indicate that export production in these regions is likely co-limited by nutrient and light availability. Overall, our results may explain the differences in carbon export measured during past iron fertilization experiments (e.g., subantarctic and polar regions), inform future iron fertilization experiments, help in the development of remotely sensed carbon export algorithms, and improve predictions of the response of marine ecosystems to a changing climate.

Data availability. Our $\mathrm{O}_{2} / \mathrm{Ar}$ measurements can be downloaded from https://sites.duke.edu/cassar/remote-sensing-export/ (Li and Cassar, 2016) 
Appendix A: Model symbols, abbreviations, and units

\begin{tabular}{|c|c|c|}
\hline Symbol & Description & Units \\
\hline MLD & Mixed layer depth & $\mathrm{m}$ \\
\hline $\operatorname{MLD}_{\mathrm{C}_{\max }^{*}}$ & Maximum MLD corresponds to maximum achievable autotroph biomass concentration & $\mathrm{m}$ \\
\hline$z \quad v^{\max }$ & Depth & $\mathrm{m}$ \\
\hline$Z_{\mathrm{c}}$ & Critical depth & $\mathrm{m}$ \\
\hline$Z_{\mathrm{p}}$ & Compensation depth & $\mathrm{m}$ \\
\hline $\operatorname{GPP}(0, z)$ & Gross primary production & $\mathrm{mmolC} \mathrm{m}{ }^{-2} \mathrm{~d}^{-1}$ \\
\hline $\operatorname{NPP}(z)$ & Net primary production at depth $z$ & $\mathrm{mmol} \mathrm{C} \mathrm{m}{ }^{-3} \mathrm{~d}^{-1}$ \\
\hline $\operatorname{NPP}(0, z)$ & Net primary production above depth $z$ & $\mathrm{mmolC} \mathrm{m}{ }^{-2} \mathrm{~d}^{-1}$ \\
\hline $\mathrm{NCP}(z)$ & Net community production at depth $z$ & $\mathrm{mmol} \mathrm{C} \mathrm{m}{ }^{-3} \mathrm{~d}^{-1}$ \\
\hline $\mathrm{NCP}(0, z)$ & Net community production above depth $z$ & $\mathrm{mmolC} \mathrm{m} \mathrm{C}^{-2} \mathrm{~d}^{-1}$ \\
\hline $\operatorname{HR}(z)$ & Heterotrophic respiration at depth $z$ & $\mathrm{mmol} \mathrm{C} \mathrm{m}{ }^{-3} \mathrm{~d}^{-1}$ \\
\hline $\operatorname{HR}(0, z)$ & Heterotrophic respiration above depth $z$ & $\mathrm{mmolC} \mathrm{m} \mathrm{C}^{-2} \mathrm{~d}^{-1}$ \\
\hline $\mathrm{NCP}^{*}$ & The maximum NCP for a given MLD (upper bound on carbon export) & $\mathrm{mmolC} \mathrm{m}{ }^{-2} \mathrm{~d}^{-1}$ \\
\hline $\mathrm{NCP}_{\mathrm{B}}$ & NCP normalized to autotroph biomass inventory in the mixed layer & $\mathrm{d}^{-1}$ \\
\hline ef & Export ratio & unitless \\
\hline$f_{\mathrm{pt}}$ & Ratio of satellite export production estimates to the upper bound on carbon export & unitless \\
\hline$N$ & Nutrient concentration & $\mathrm{mmol} \mathrm{m}^{-3}$ \\
\hline$k_{\mathrm{m}}^{\mathrm{N}}$ & Half-saturation constant for nutrient concentration & $\mathrm{mmolm}^{-3}$ \\
\hline$N_{\mathrm{m}}$ & Nutrient effect on phytoplankton growth $N_{\mathrm{m}}=\frac{N}{N+k^{\mathrm{N}}}$ & unitless \\
\hline PAR & Photosynthetically active radiation & einstein $\mathrm{m}^{-2} \mathrm{~d}^{-1}$ \\
\hline$I_{0}$ & Photosynthetically active radiation just beneath water surface & einstein $\mathrm{m}^{-2} \mathrm{~d}^{-1}$ \\
\hline$I(z)$ & Photosynthetically active radiation at depth $z$ & einstein $\mathrm{m}^{-2} \mathrm{~d}^{-1}$ \\
\hline$k_{\mathrm{m}}^{I}$ & Half-saturation constant for irradiance & einstein $\mathrm{m}^{-2} \mathrm{~d}^{-1}$ \\
\hline$I_{\mathrm{m}}(z)$ & Light effect on phytoplankton growth at depth $z, I_{\mathrm{m}}(z)=\frac{I(z)}{I(z)+k_{\mathrm{m}}^{\Gamma}}=\frac{I_{0} \cdot e^{-K_{\mathrm{I}} \cdot z}}{I_{0} \cdot e^{-K_{\mathrm{I}} \cdot z+k_{\mathrm{m}}^{\mathrm{I}}}}$ & unitless \\
\hline$I_{\mathrm{m}}(0, z)$ & Integrated light effect on phytoplankton growth above depth $z, I_{\mathrm{m}}(0, z)=-\frac{1}{K_{\mathrm{I}}} \cdot \ln \left(\frac{I_{0} \cdot e^{-K_{\mathrm{I}} \cdot z}+k_{\mathrm{m}}^{\mathrm{I}}}{I_{0}+k_{\mathrm{m}}^{\mathrm{I}}}\right)$ & unitless \\
\hline $\mathrm{PAR}_{\mathrm{ML}}$ & Average PAR in the mixed layer $\left(\mathrm{PAR}_{\mathrm{ML}}=\frac{1-e^{-K_{\mathrm{I}} \cdot \mathrm{MLD}}}{K_{\mathrm{I}} \cdot \mathrm{MLD}} \cdot I_{0}\right)$ & einstein $\mathrm{m}^{-2} \mathrm{~d}^{-1}$ \\
\hline$\mu$ & Phytoplankton growth rate & $\mathrm{d}^{-1}$ \\
\hline$\mu_{\max }$ & Maximum phytoplankton growth rate & $\mathrm{d}^{-1}$ \\
\hline$\mu_{\max }^{0}$ & Maximum phytoplankton growth rate for $T=0{ }^{\circ} \mathrm{C}$ & $\mathrm{d}^{-1}$ \\
\hline$r_{\mathrm{HR}}$ & Heterotrophic respiration ratio & $d^{-1}$ \\
\hline$r_{\mathrm{HR}}^{0}$ & Heterotrophic respiration ratio for $T=0{ }^{\circ} \mathrm{C}$ & $d^{-1}$ \\
\hline$K_{\mathrm{I}}$ & Light attenuation coefficient $\left(K_{\mathrm{I}}=K_{\mathrm{I}}^{\mathrm{W}}+K_{\mathrm{I}}^{\mathrm{nw}}\right)$ & $\mathrm{m}^{-1}$ \\
\hline$K_{\mathrm{I}}^{\mathrm{W}}$ & Light attenuation coefficient due to water & $\mathrm{m}^{-1}$ \\
\hline$K_{\mathrm{I}}^{\mathrm{nw}}$ & Light attenuation coefficient due to optically active components & $\mathrm{m}^{-1}$ \\
\hline$k_{\mathrm{c}}$ & Specific attenuation coefficient for irradiance & $\mathrm{m}^{2} \mathrm{mmol}^{-1}$ \\
\hline$C$ & Phytoplankton biomass concentration & $\mathrm{mmolm}^{-3}$ \\
\hline$C^{*}$ & Phytoplankton biomass concentration that maximizes NCP & $\mathrm{mmol} \mathrm{m}^{-3}$ \\
\hline$C_{\max }^{*}$ & Maximum achievable autotroph biomass concentration & $\mathrm{mmolm}^{-3}$ \\
\hline POC & Particulate organic carbon & $\mathrm{mmol} \mathrm{m}^{-3}$ \\
\hline DOC & Dissolved organic carbon & $\mathrm{mmolm}^{-3}$ \\
\hline CDOM & Colored dissolved organic matter & $\mathrm{m}^{-1}$ \\
\hline NAP & Non-algal particles & $\mathrm{mmolm}^{-3}$ \\
\hline$T$ & Temperature & ${ }^{\circ} \mathrm{C}$ \\
\hline$P_{\mathrm{t}}$ & Temperature dependence for phytoplankton growth rate & ${ }^{\circ} \mathrm{C}^{-1}$ \\
\hline$B_{\mathrm{t}}$ & Temperature dependence for heterotrophic respiration ratio & ${ }^{\circ} \mathrm{C}^{-1}$ \\
\hline $\mathrm{CO}_{2}$ & Carbon dioxide & ppmv \\
\hline
\end{tabular}




\section{The Supplement related to this article is available online at https://doi.org/10.5194/bg-14-5015-2017-supplement.}

Competing interests. The authors declare that they have no conflict of interest.

Acknowledgements. We would like to acknowledge NASA GSFC for processing and distributing PAR and SST products (http://oceancolor.gsfc.nasa.gov/). Global Argo temperature-salinity profiling floats were downloaded from http://www.usgodae.org/. CTD casts were downloaded from the National Oceanographic Data Center (https://www.nodc.noaa.gov/). NC was supported by NSF OPP-1043339. ZL was supported by a NASA Earth and Space Science Fellowship (grant no. NNX13AN85H). The authors thank three anonymous reviewers for their insightful comments.

Edited by: Jack Middelburg

Reviewed by: three anonymous referees

\section{References}

Arrigo, K. R., van Dijken, G. L., and Bushinsky, S.: Primary production in the Southern Ocean, 1997-2006, J. Geophys. Res., 113, C08004, https://doi.org/10.1029/2007JC004551, 2008.

Baker, K. S. and Smith, R. C.: Bio-optical classification and model of natural waters. 2, Limnol. Oceanogr., 27, 500-509, https://doi.org/10.4319/lo.1982.27.3.0500, 1982.

Behrenfeld, M. J.: Abandoning Sverdrup's Critical Depth Hypothesis on phytoplankton blooms, Ecology, 91, 977-989, https://doi.org/10.1890/09-1207.1, 2010.

Behrenfeld, M. J. and Falkowski, P. G.: Photosynthetic rates derived from satellite-based chlorophyll concentration, Limnol. Oceanogr., 42, 1-20, https://doi.org/10.4319/lo.1997.42.1.0001, 1997.

Bender, M. L., Tilbrook, B., Cassar, N., Jonsson, B. F., Poisson, A., and Trull, T. W.: Ocean productivity south of Australia during spring and summer, Deep-Sea Res. Pt. I, 112, 68-78, https://doi.org/10.1016/j.dsr.2016.02.018, 2016.

Bender, M. L., Kinter, S., Cassar, N., and Wanninkhof, R.: Evaluating gas transfer velocity parameterizations using upper ocean radon distributions, J. Geophys. Res., 116, https://doi.org/10.1029/2009JC005805, 2011.

Bissinger, J. E., Montagnes, D. J. S., Sharples, J., and Atkinson, D.: Predicting marine phytoplankton maximum growth rates from temperature: Improving on the Eppley curve using quantile regression, Limnol. Oceanogr., 53, 487-493, https://doi.org/10.4319/lo.2008.53.2.0487, 2008.

Boss, E. and Behrenfeld, M. J.: In situ evaluation of the initiation of the North Atlantic phytoplankton bloom, Geophys. Res. Lett., 37, https://doi.org/10.1029/2010GL044174, 2010.

Boyd, P. W., Jickells, T., Law, C. S., Blain, S., Boyle, E. A., Buesseler, K. O., Coale, K. H., Cullen, J. J., de Baar, H. J. W., Follows, M., Harvey, M., Lancelot, C., Levasseur, M.,
Owens, N. P. J., Pollard, R., Rivkin, R. B., Sarmiento, J., Schoemann, V., Smetacek, V., Takeda, S., Tsuda, A., Turner, S., and Watson, A. J.: Mesoscale iron enrichment experiments 19932005: Synthesis and future directions, Science, 315, 612-617, https://doi.org/10.1126/science.1131669, 2007.

Boyd, P. W., Watson, A. J., Law, C. S., Abraham, E. R., Trull, T., Murdoch, R., Bakker, D. C. E., Bowie, A. R., Buesseler, K. O., Chang, H., Charette, M., Croot, P., Downing, K., Frew, R., Gall, M., Hadfield, M., Hall, J., Harvey, M., Jameson, G., LaRoche, J., Liddicoat, M., Ling, R., Maldonado, M. T., McKay, R. M., Nodder, S., Pickmere, S., Pridmore, R., Rintoul, S., Safi, K., Sutton, P., Strzepek, R., Tanneberger, K., Turner, S., Waite, A., and Zeldis, J.: A mesoscale phytoplankton bloom in the polar Southern Ocean stimulated by iron fertilization, Nature, 407, 695-702, https://doi.org/10.1038/35037500, 2000.

Britten, G. L., Wakamatsu, L., and Primeau, F. W.: The temperatureballast hypothesis explains carbon export efficiency observations in the Southern Ocean, Geophys. Res. Lett., 44, 1831-1838, https://doi.org/10.1002/2016GL072378, 2017.

Brody, S. R. and Lozier, M. S.: Characterizing upper-ocean mixing and its effect on the spring phytoplankton bloom with in situ data, ICES J. Mar. Sci., 72, 1961-1970, https://doi.org/10.1093/icesjms/fsv006, 2015.

Cael, B. B. and Follows, M. J.: On the temperature dependence of oceanic export efficiency, Geophys. Res. Lett., 43, 5170-5175, https://doi.org/10.1002/2016GL068877, 2016.

Cael B. B., Bisson, K., and Follows, M. J.: How have recent temperature changes affected the efficiency of ocean biological carbon export?, Limnol. Oceanogr., 2, 113-118, https://doi.org/10.1002/lol2.10042, 2017.

Cassar, N., Nevison, C. D., and Manizza, M.: Correcting oceanic $\mathrm{O}_{2}$ /Ar-net community production estimates for vertical mixing using $\mathrm{N}_{2} \mathrm{O}$ observations, Geophys. Res. Lett., 41, 8961-8970, https://doi.org/10.1002/2014GL062040, 2014.

Cassar, N., DiFiore, P. J., Barnett, B. A., Bender, M. L., Bowie, A. R., Tilbrook, B., Petrou, K., Westwood, K. J., Wright, S. W., and Lefevre, D.: The influence of iron and light on net community production in the Subantarctic and Polar Frontal Zones, Biogeosciences, 8, 227-237, https://doi.org/10.5194/bg-8-2272011, 2011.

Cassar, N., Wright, S. W., Thomson, P. G., Trull, W. T., Westwood, K. J., de Salas, M., Davidson, A., Pearce, I., Davies, D. M., and Matear, R. J.: The relation of mixed-layer net community production to phytoplankton community composition in the Southern Ocean, Global Biogeochem. Cy., 29, 446-462, https://doi.org/10.1002/2014GB004936, 2015.

Chang, C.-H., Johnson, N. C., and Cassar, N.: Neural networkbased estimates of Southern Ocean net community production from in situ $\mathrm{O}_{2} / \mathrm{Ar}$ and satellite observation: a methodological study, Biogeosciences, 11, 3279-3297, https://doi.org/10.5194/bg-11-3279-2014, 2014.

Chen, B. and Laws, E. A.: Is there a difference of temperature sensitivity between marine phytoplankton and heterotrophs?, Limnol. Oceanogr., 62, 806-817, https://doi.org/10.1002/lno.10462, 2017.

Cullen, J. J. and Lewis, M. R.: The kinetics of algal photoadaptation in the context of vertical mixing, J. Plankton Res., 10, 10391063, https://doi.org/10.1093/plankt/10.5.1039, 1988. 
de Barr, J. W. H., Boyd, P. W., Coale, K. H., Landry M. R., Tsuda, A., Assmy, P., Bakker, D. C. E., Bozec, Y., Barber, R. T., Brzezinski, M. A., Buesseler, K. O., Boyé, M., Croot, P. L., Gervais, F., Gorbunov, M. Y., Harrison, P. J., Hiscock, W. T., Laan, P., Lancelot, C., Law, C. S., Levasseur, M., Marchetti, A., Millero, F. J., Nishioka, J., Nojiri, Y., van Oijen, T., Riebesell, U., Rijkenberg, M. J. A., Saito, H., Takeda, S., Timmermans, K. R., Veldhuis, M. J. W., Waite, A. M., and Wong, C. S.: Synthesis of iron fertilization experiments: From the Iron age in the Age of Enlightenment, J. Geophys. Res., 110, C09S16, https://doi.org/10.1029/2004JC002601, 2005.

Dunne, J. P., Armstrong, R. A., Gnanadesikan, A., and Sarmiento, J. L.: Empirical and mechanistic models for the particle export ratio, Global Biogeochem. Cy., 19, https://doi.org/10.1029/2004GB002390, 2005.

Duteil, O., Koeve, W., Oschlies, A., Bianchi, D., Galbraith, E., Kriest, I., and Matear, R.: A novel estimate of ocean oxygen utilisation points to a reduced rate of respiration in the ocean interior, Biogeosciences, 10, 7723-7738, https://doi.org/10.5194/bg-107723-2013, 2013.

Dutkiewicz, S., Follows, M., Marshall, J., and Gregg, W. W.: Interannual variability of phytoplankton abundances in the North Atlantic, Deep-Sea Res. Pt. II, 48, 2323-2344, https://doi.org/10.1016/S0967-0645(00)00178-8, 2001

Edwards, K. F., Thomas, M. K., Klausmeier, C. A., and Litchman, E.: Phytoplankton growth and the interaction of light and temperature: A synthesis at the species and community level, Limnol. Oceanogr., 61, 1232-1244, https://doi.org/10.1002/lno.10282, 2016.

Eppley, R. W.: Temperature and phytoplankton growth in the sea, Fish. B.-NOAA, 70, 1063-1085, 1972.

Eveleth, R., Cassar, N., Sherrell, R. M., Ducklow, H., Meredith, M., Venables, H., Lin, Y., and Li, Z.: Ice melt influence on summertime net community production along the Western Antarctic Peninsula, Deep-Sea Res. Pr. II, 139, 89-102, https://doi.org/10.1016/j.dsr2.2016.07.016, 2017.

Falkowski, P. G., Barber, R. T., and Smetacek, V.: Biogeochemical controls and feedbacks on ocean primary production, Science, 281, 200-206, https://doi.org/10.1126/science.281.5374.200, 1998.

Franks, P. J. S.: Has Sverdrup's critical depth hypothesis been tested? Mixed layers vs. turbulent layers, ICES J. Mar. Sci., 72, 1897-1907, https://doi.org/10.1093/icesjms/fsu175, 2015.

Gong, X., Shi, J., Gao, H. W., and Yao, X. H.: Steady-state solutions for subsurface chlorophyll maximum in stratified water columns with a bell-shaped vertical profile of chlorophyll, Biogeosciences, 12, 905-919, https://doi.org/10.5194/bg-12-9052015, 2015.

Gong, X., Jiang, W., Wang, L., Gao, H., Boss, E., Yao, X., Kao, S., and Shi, J.: Analytical solution of the nitracline with the evolution of subsurface chlorophyll maximum in stratified water columns, Biogeosciences, 14, 2371-2386, https://doi.org/10.5194/bg-14-2371-2017, 2017.

Gordon, H. R.: Can the Lambert-Beer law be applied to the diffuse attenuation coefficient of ocean water? Limnol. Oceanogr., 34, 1389-1409, https://doi.org/10.4319/lo.1989.34.8.1389, 1989.

Henson, S. A., Yool, A., and Sanders, R.: Variability in efficiency of particulate organic carbon export:
A model study, Global Biogeochem. Cy., 29, 33-45, https://doi.org/10.1002/2014GB004965, 2015.

Henson, S. A., Sanders, R., Madsen, E., Morris, P. J., Le Moigne, F., and Quartly, G. D.: A reduced estimate of the strength of the ocean's biological carbon pump, Geophys. Res. Lett., 38, L04606, https://doi.org/10.1029/2011GL046735, 2011.

Huang, K., Ducklow, H., Vernet, M., Cassar, N., and Bender, M. L.: Export production and its regulating factors in the West Antarctica Peninsula region of the Southern Ocean, Global Biogeochem. Cy., 26, GB2005, https://doi.org/10.1029/2010GB004028, 2012.

Huisman, J. and Weissing, F. J.: Light-limited growth and competition for light in well-mixed aquatic environments: An elementary model, Ecology, 75, 507-520, https://doi.org/10.2307/1939554, 1994.

Huisman, J., van Oostveen, P., and Weissing, F. J.: Critical depth and critical turbulence: Two different mechanisms for the development of phytoplankton blooms, Limnol. Oceanogr., 44, 17811787, https://doi.org/10.4319/lo.1999.44.7.1781, 1999.

Huisman, J., Thi, N. N. P., Karl, D. M., and Sommeijer B.: Reduced mixing generates oscillations and chaos in the oceanic deep chlorophyll maximum, Nature, 439, 322-325, https://doi.org/10.1038/nature04245, 2006.

Ito, T. and Follows, M. J.: Preformed phosphate, soft tissue pump and atmospheric $\mathrm{CO}_{2}$, J. Mar. Res., 63, 813-839, https://doi.org/10.1357/0022240054663231, 2005.

Jonsson, B. F., Doney, S. C., Dunne, J., and Bender, M.: Evaluation of the Southern Ocean $\mathrm{O}_{2} /$ Ar-based NCP estimates in a model framework, J. Geophys. Res., 118, 385-399, https://doi.org/10.1002/jgrg.20032, 2013.

Kremer, C. T., Thomas, M. K., and Litchman, E.: Temperatureand size-scaling of phytoplankton population growth rates: Reconciling the Eppley curve and the metabolic theory of ecology, Limnol. Oceanogr., 62, 1658-1670, https://doi.org/10.1002/lno.10523, 2017.

Laws, E. A., Falkowski, P. G., Smith, W. O., Ducklow, H., and McCarthy, J. J.: Temperature effects on export production in the open ocean, Global Biogeochem. Cy., 14, 1231-1246, https://doi.org/10.1029/1999GB001229, 2000.

Lewis, M. R., Cullen, J. J., and Platt, T.: Relationships between vertical mixing and photoadaptation of phytoplankton: Similarity criteria, Mar. Ecol. Prog. Ser., 15, 141-149, https://doi.org/10.3354/meps015141, 1984.

Li, Z. and Cassar, N.: Satellite estimates of net community production based on $\mathrm{O}_{2} / \mathrm{Ar}$ observations and comparison to other estimates, Global Biogeochem. Cy., 30, 735-752, https://doi.org/10.1002/2015GB005314, 2016.

Li, Z., Cassar, N., Huang, K., Ducklow, H., and Schofield, O.: Interannual variability in net community production at the Western Antarctic Peninsula region (1997-2014), J. Geophys. Res., 121, 4748-4762, https://doi.org/10.1002/2015JC011378, 2016.

López-Urrutia, A. and Morán, X. A. G.: Resource limitation of bacterial production distorts the temperature dependence of oceanic carbon cycling, Ecology, 88, 817-822, https://doi.org/10.1890/06-1641, 2007.

López-Urrutia, Á., San Martin, E., Harris, R. P., and Irigoien, $X$.: Scaling the metabolic balance of the oceans, P. Natl Acad. Sci. USA, 103, 8739-8744, https://doi.org/10.1073/pnas.0601137103, 2006. 
Maiti, K., Charette, M. A., Buesseler, K. O., and Kahru M.: An inverse relationship between production and export efficiency in the Southern Ocean, Geophys. Res. Lett., 40, 1557-1561, https://doi.org/10.1002/grl.50219, 2013.

Martin, J. H., Knauer, G. A., Karl, D. M., and Broenkow, W. W.: VERTEX: carbon cycling in the northeast Pacific, Deep-Sea Res., 34, 267-285, https://doi.org/10.1016/01980149(87)90086-0, 1987.

Martin, P., Rutgers van der Loeff, M., Cassar, N., Vandromme, P., d'Ovidio, F., Stemman, L., Rengarajan, R., Soares, M., Gonzalez, H. E., Ebersbach, F., Lampitt, R., Sanders, R., Barnett, B., Smetacek, V., and Naqvi, S. W. A.: Iron fertilization enhanced net community production but not downward particle flux during the Southern Ocean iron fertilization experiment LOHAFEX, Global Biogeochem. Cy., 27, 871-881, https://doi.org/10.1002/gbc.20077, 2013.

Mitchell, B. G. and Holm-Hansen, O.: Observations and modeling of the Antarctic phytoplankton crop in relation to mixing depth, Deep-Sea Res., 38, 981-1007, https://doi.org/10.1016/01980149(91)90093-U, 1991.

Mitchell, B. G., Brody, E. A., Holm-Hansen, O., McClain, C., and Bishop, J.: Light limitation of phytoplankton biomass and macronutrient utilization in the Southern Ocean, Limnol. Oceanogr., 36, 1662-1677, https://doi.org/10.4319/lo.1991.36.8.1662, 1991.

Morel, A. and Prieur, L.: Analysis of variations in ocean color, Limnol. Oceanogr., 22, 709-722, https://doi.org/10.4319/lo.1977.22.4.0709, 1977.

Mouw, C. B., Barnett, A., McKinley, G., Gloege, L., and Pilcher, D.: Global ocean particulate organic carbon flux merged with satellite parameters, Earth Syst. Sci. Data, 8, 531-541, https://doi.org/10.5194/essd-8-531-2016, 2016.

Nelson, D. M. and Smith, W. O.: Sverdrup revisited: Critical depths, maximum chlorophyll levels, and the control of Southern Ocean productivity by the irradiancemixing regime, Limnol. Oceanogr., 36, 1650-1661, https://doi.org/10.4319/lo.1991.36.8.1650, 1991.

Platt, T., Gallegos, C. L., and Harrison, W. G.: Photoinhibition of photosynthesis in natural assemblages of marine phytoplankton, J. Mar. Res., 38, 687-701, 1980.

Rivkin, R. B. and Legendre, L.: Biogenic carbon cycling in the upper ocean: Effects of microbial respiration, Science, 291, 23982400, https://doi.org/10.1126/science.291.5512.2398, 2001.

Sarmiento, J. L. and Gruber, N.: Ocean Biogeochemical Dynamics, Princeton University Press, Princeton, New Jersey, 2006.

Shadwick, E. H., Tilbrook, B., Cassar, N., Trull, T. W., and Rintoul, S. R.: Summertime physical and biological controls on $\mathrm{O}_{2}$ and $\mathrm{CO}_{2}$ in the Australian Sector of the Southern Ocean, J. Marine Syst., 147, 21-28, https://doi.org/10.1016/j.jmarsys.2013.12.008, 2015.

Siegel, D. A., Buesseler, K. O., Behrenfeld, M. J., Benitez-Nelson, C. R., Boss, E., Brzezinski, M. A., Burd, A., Carlson, C. A., D’Asaro, E. A., Doney, S. C., Perry, M. J., Stanley, R. H. R., and Steinberg, D. K.: Prediction of the export and fate of global ocean net primary production: The exports science plan, Front. Mar. Sci., 3, 22 pp., https://doi.org/10.3389/fmars.2016.00022, 2016.
Sigman, D. M. and Boyle, E. A.: Glacial/interglacial variations in atmospheric carbon dioxide, Nature, 407, 859-869, https://doi.org/10.1038/35038000, 2000.

Smetacek, V. and Passow, U.: Spring bloom initiation and Sverdrup's critical depth model, Limnol. Oceanogr., 35, 228-234, https://doi.org/10.4319/lo.1990.35.1.0228, 1990.

Smith, R. C. and Baker, K. S.: Optical classification of natural waters, Limnol. Oceanogr., 23, 260-267, https://doi.org/10.4319/lo.1978.23.2.0260, 1978a.

Smith, R. C. and Baker, K. S.: The bio-optical state of ocean waters and remote sensing, Limnol. Oceanogr., 23, 247-259, https://doi.org/10.4319/lo.1978.23.2.0247, 1978b.

Stange, P., Bach, L. T., Le Moigne, F. A. C., Taucher, J., Boxhammer, T., and Riebesell, U.: Quantifying the time lag between organic matter production and export in the surface ocean: Implications for estimates of export efficiency, Geophys. Res. Lett., 44, 268-276, https://doi.org/10.1002/2016GL070875, 2017.

Sunda, W. G. and Huntsman, S. A.: Interrelated influence of iron, light and cell size on marine phytoplankton growth, Nature, 390 , 389-392, https://doi.org/10.1038/37093, 1997.

Sverdrup, H. U.: On conditions for the vernal blooming of phytoplankton, Journal du Conseil International pour l'Exploration de la Mer, 18, 287-295, https://doi.org/10.1093/icesjms/18.3.287, 1953.

Taylor, J. R. and Ferrari, R.: Shutdown of turbulent convection as a new criterion for the onset of spring phytoplankton blooms, Limnol. Oceanogr., 56, 2293-2307, https://doi.org/10.4319/lo.2011.56.6.2293, 2011.

Tortell, P. D., Bittig, H. C., Körtzinger, A., Jones, E. M., and Hoppema, M.: Biological and physical controls on $\mathrm{N}_{2}$, $\mathrm{O}_{2}$, and $\mathrm{CO}_{2}$ distributions in contrasting Southern Ocean surface waters, Global Biogeochem. Cy., 29, 994-1013, https://doi.org/10.1002/2014GB004975, 2015.

Volk, T. and Hoffert, M. I.: Ocean carbon pumps: Analysis of relative strengths and efficiencies in ocean-driven atmospheric $\mathrm{CO}_{2}$ changes, in: The Carbon Cycle and Atmospheric $\mathrm{CO}_{2}$ : Natural Variations Archean to Present, edited by Sundquist, E. T. and Broecker, W. S., AGU, Washington, D. C., Geophys. Monogr. Ser., 32, 99-110, 1985.

Werdell, P. J. and Bailey, S. W.: An improved in-situ bio-optical data set for ocean color algorithm development and satellite data product validation, Remote Sens. Environ., 98, 122-140, https://doi.org/10.1016/j.rse.2005.07.001, 2005.

White, P. A., Kalff, J., Rasmussen, J. B., and Gasol, J. M.: The effect of temperature and algal biomass on bacterial production and specific growth rate in fresh water and marine habitats, Microb. Ecol., 21, 99-118, https://doi.org/10.1007/BF02539147, 1991. 